\section{Pattern of Maxillofacial Fractures in Severe Multiple Trauma Patients: A 7-year Prospective Study}

La-Salete Alves ${ }^{1}$, Irene Aragão², Maria-José Carneiro Sousa² ${ }^{2}$ Ernestina Gomes ${ }^{3}$

\author{
'Abel Salazar Biomedical Sciences \\ Institute, Oporto, Portugal \\ ${ }^{2}$ General Intensive Care Unit, Santo \\ Antonio Hospital, Oporto, Portugal \\ ${ }^{3}$ Pedro Hispano Hospital, \\ Intensive Medical Service, \\ Senhora da Hora, Portugal
}

Correspondence: La Salete Alves, Rua de Jorge Viterbo Ferreira, 228, 4050-313 Porto, Portugal. Tel.: +351-96-458-2521. e-mail: lasaletealves@gmail.com

Key Words: maxillofacial injury, fracture, multiple traumas, traffic accident.

\begin{abstract}
The incidence of facial trauma is high. This study has the primary objective of documenting and cataloging maxillofacial fractures in polytrauma patients. From a total of 1229 multiple trauma cases treated at the Emergency Room of the Santo Antonio Hospital - Oporto Hospital Center, Portugal, between August 2001 and December 2007, 251 patients had facial wounds and 209 had maxillofacial fractures. Aged ranged form 13 to 86 years. The applied selective method was based on the presence of facial wound with Abbreviated Injury Scale $\geq 1$. Men had a higher incidence of maxillofacial fractures among multiple trauma patients $(86.6 \%)$ and road traffic accidents were the primary cause of injuries (69.38\%). Nasoorbitoethmoid complex was the most affected region (67.46\%) followed by the maxilla (57.42\%). The pattern and presentation of maxillofacial fractures had been studied in many parts of the world with varying results. Severe multiple trauma patients had different patterns of maxillofacial injuries. The number of maxillofacial trauma is on the rise worldwide as well as the incidence of associated sequelae. Maxillofacial fractures on multiple trauma patients were more frequent among males and in road traffic crashes. Knowing such data is elementary. The society should have a key role in the awareness of individuals and in prevention of road traffic accidents.
\end{abstract}

\section{Introduction}

There has always been a great diversification of human exposure to aggressive agents, making them progressive targets of numerous types of trauma, including maxillofacial fractures. Facial traumata have a multifactorial etiology, such as road traffic accidents (1), where motorcyclerelated incidents are a significant part (2), occupational accidents (3), sports accidents (4), domestic accidents (5), interpersonal violence (6), terrorism (7) and war (8).

Due to cultural, environmental and socioeconomic factors, causes for maxillofacial trauma differ worldwide (9). Hence epidemiological studies are used to analyze the incidence and pattern of etiology, frequency and severity of maxillofacial and dental trauma (10). Among European countries, Portugal has high rates of trauma occurrence and mortality. According to the 2010 Statistical Yearbook of Portugal (from the National Statistics Institute), a total of 35,426 road traffic accidents were recorded, 424 of which were fatal (11). Several literature reviews about industrialized countries indicate assault as another major cause (12). The face plays a crucial role in the presentation of the human being and thus is prone to assaults, which often results in irreparable damages and disfigurement (13).

In Portugal, there is little data concerning maxillofacial and dental trauma in severe multiple trauma patients $(14,15)$. As an effective injury prevention effort depends on reliable and detailed information on the incidence, causes and pattern of injury, periodic epidemiological studies are imperative. The purpose of this 7-year study was to analyze the maxillofacial fractures treated at the Santo Antonio Hospital - Oporto Hospital Center, Portugal, with specific emphasis on the connection between age and diversity, incidence, fracture pattern and suggested improvements.

\section{Material and Methods}

A cohort study for the emergency room of the Santo Antonio Hospital - Oporto Hospital Center was designed for the time frame between August 2001 and December 2007. A total of 1,229 severe multiple trauma patients were admitted to the emergency room. The sample group consisted of 251 patients with maxillofacial trauma, 209 of them with maxillofacial fractures. The Santo Antonio Hospital is a tertiary and university hospital as well as the prior hospital for multiple trauma patients with head injuries in Northern Portugal. The method of selection applied was based on the presence of facial wounds with an Abbreviated Injury Scale (AIS) $\geq 1$ (16). Ethical approval was obtained from the institution's ethics committee.

The study recorded details of patients' sex, age group, mean age, type of injury, mechanism of injury, hospital 1 (first care), hospital length of stay (LOS), intensive care unit length of stay (ICU LOS), associated injuries, distribution of maxillofacial fractures, distribution of mandibular fractures, ward, number of maxillofacial surgeries, hospital mortality, mortality after hospital discharge. The injury mechanisms were grouped into six categories: road traffic accident, 
Table 1. Details of patients

\begin{tabular}{|c|c|c|c|c|}
\hline Data & $\begin{array}{c}\text { Total } \\
(n=209)\end{array}$ & $\begin{array}{l}\text { Survivors } \\
(n=135)\end{array}$ & $\begin{array}{c}\text { Deaths in } \\
\text { hospital }(n=44)\end{array}$ & $\begin{array}{c}\text { Deaths after } \\
\text { discharge }(n=30)\end{array}$ \\
\hline \multicolumn{5}{|l|}{ Gender, n (\%) } \\
\hline Male & $181(86.60)$ & $119(88.15)$ & $34(77.27)$ & $28(93.33)$ \\
\hline Female & $28(13.40)$ & $16(11.85)$ & $10(22.73)$ & $2(6.67)$ \\
\hline \multicolumn{5}{|l|}{ Age group, n (\%) } \\
\hline $10-14$ & $5(2.39)$ & $4(2.96)$ & $1(2.27)$ & $0(0)$ \\
\hline $15-19$ & $30(14.35)$ & $24(17.78)$ & $6(13.64)$ & $0(0)$ \\
\hline $20-24$ & $24(11.48)$ & 17 (12.59) & $5(11.36)$ & $2(6.67)$ \\
\hline $25-29$ & $22(10.53)$ & $16(11.85)$ & $5(11.36)$ & $1(3.33)$ \\
\hline $30-39$ & 34 (16.27) & 22 (16.30) & 10 (22.73) & $2(6.67)$ \\
\hline $40-49$ & $33(15 ., 79)$ & $26(19.26)$ & $5(11.36)$ & $2(6.67)$ \\
\hline $50-59$ & $23(11.0)$ & $14(10.37)$ & $5(11.36)$ & $4(13.33)$ \\
\hline $60-69$ & $15(7.18)$ & $6(4.44)$ & $3(6.81)$ & $6(20.0)$ \\
\hline $70-79$ & $20(9.57)$ & $6(4.44)$ & $4(9.09)$ & $10(33.33)$ \\
\hline 80-89 & $3(1.44)$ & $0(0)$ & $0(0)$ & $3(10.0)$ \\
\hline Age, mean (min-max) & $45(14-86)$ & $37(14-76)$ & $36(14-78)$ & $58(16-86)$ \\
\hline \multicolumn{5}{|l|}{ Type of Injury, n (\%) } \\
\hline Penetrating & $11(5.26)$ & $4(2.96)$ & $5(11.36)$ & $2(6.67)$ \\
\hline Blunt & 198 (94.74) & $131(97.04)$ & 39 (88.64) & 28 (93.33) \\
\hline \multicolumn{5}{|c|}{ Mechanism of injury, n (\%) } \\
\hline Road traffic accidents & $145(69.38)$ & 95 (70.37) & $30(68.18)$ & $20(66.67)$ \\
\hline Occupational accident & $35(16.75)$ & $27(20.0)$ & $6(13.64)$ & $2(6.67)$ \\
\hline Domestic accident & $18(8.61)$ & $8(5.93)$ & $4(9.09)$ & $6(20.0)$ \\
\hline Assault & $6(2.87)$ & $3(2.22)$ & $2(4.55)$ & $1(3.33)$ \\
\hline Railroad accident & $1(0.48)$ & $0(0)$ & $1(2.27)$ & $0(0)$ \\
\hline Other & $4(1.91)$ & $2(1.48)$ & $1(2.27)$ & $1(3.33)$ \\
\hline Hospital 1, n (\%) & 83 (39.71) & 51 (37.78) & $20(45.45)$ & $12(40.0)$ \\
\hline Hospital LOS, mean & $32(1-235)$ & $30(2-123)$ & $11(1-45)$ & $26(1-235)$ \\
\hline 1CU LOS, mean & $14(1-33)$ & $13(1-31)$ & $10(1-32)$ & $12(1-33)$ \\
\hline \multicolumn{5}{|l|}{ Associated injuries, $\mathrm{n}(\%)$} \\
\hline Face & $209(100.0)$ & $135(100.0)$ & $44(100.0)$ & $30(100.0)$ \\
\hline Head & $181(86.60)$ & $130(96.30)$ & $31(70.45)$ & $20(66.67)$ \\
\hline Thorax & $105(50.24)$ & 68 (50.37) & $23(52.27)$ & $14(46.67)$ \\
\hline Lombar & $14(6.70)$ & $11(8.45)$ & $1(2.27)$ & $2(6.67)$ \\
\hline Cervical & $24(11.48)$ & $14(10.37)$ & $6(13.64)$ & $4(13.33)$ \\
\hline Spinal & $10(4.78)$ & $3(2.22)$ & $1(2.27)$ & $6(20.0)$ \\
\hline Abdominal & $26(12.44)$ & 17 (12.59) & $6(13.64)$ & $3(10.0)$ \\
\hline Pelvis & $26(12.44)$ & $1(0.74)$ & $5(11.36)$ & 7 (23.33) \\
\hline Lower limb & 71 (33.97) & $52(38.52)$ & $13(29.54)$ & $6(20.0)$ \\
\hline Upper limb & $51(24.40)$ & 36 (26.67) & $7(15.91)$ & $8(26.67)$ \\
\hline
\end{tabular}

LOS: Length Of Stay, ICU: Intensive Care Unit. occupational accident, domestic accident, assault, railroad accident and others. Associated injuries were differentiated into: head, thorax, lumbar, cervical, spinal, abdominal, pelvic, lower and upper limbs. Fractures were grouped into: Le Fort, nasoorbitoethmoid complex (NOE), zygomatic complex, mandible and maxilla.

Mortality was also accounted for. For mortality after hospital discharge, three periods were considered: $<6$ months, 6-12 months, and $>12$ months. Hospital mortality was divided into three periods as well: early (2 or less days), overall ( 2 days) and late (more than 2 days). The number of maxillofacial surgeries was grouped into four categories: 1, 2, 3 and more than 3 surgeries. Wards were categorized as neurosurgery, maxillofacial surgery/ stomatology, ophthalmology and otorhinolaryngology. Data collection was completed in September 2012, after all patients had been clinically discharged.

\section{Results}

Table 1 contains details on the patients. The age range spanned from 14 to 86 years (mean 45). The overall male-female ratio was $6,46: 1$. The majority of trauma $(16,27 \%)$ occurred amongst the 30-39 year age group. The most common etiologic factor for trauma was road traffic accidents with $69.38 \%$. Other causes included occupational accidents (16.75\%), domestic accidents (8.61\%), assaults $(2.87 \%)$ and railroad accidents (0.48\%).

A total of 198 (94.74\%) individuals had blunt injuries and Santo Antonio Hospital was the hospital 1 in $83(39.71 \%)$ cases. The hospital LOS mean was 32 days and the ICU-LOS was 14. As for associated injuries, a total of $86.6 \%$ patients presented head 
injuries (and simultaneous traumatic brain injury); of all patients, 50.24\% had thorax injuries, $12.44 \%$ had pelvic and $12.44 \%$ abdominal injuries.

A total of 546 maxillofacial fractures in 209 patients were examined, with a mean of 2.62 fractures per patient, representing $83.27 \%$ of all recorded maxillofacial trauma. In this patient group, 181 (86.6\%) were male. The nasoorbitoethmoid complex fractures occurred 141 times (67.46\%) and maxillary fractures 120 times (57.42\%).

Table 2. Distribution of maxillofacial fractures $(n=209)$.

\begin{tabular}{lcccc}
\hline $\begin{array}{l}\text { Maxillofacial } \\
\text { fractures }\end{array}$ & $\begin{array}{c}\text { Total } \\
(\mathrm{n}=209)\end{array}$ & $\begin{array}{c}\text { Survivors } \\
(\mathrm{n}=135)\end{array}$ & $\begin{array}{c}\text { Deaths in } \\
\text { hospital } \\
(\mathrm{n}=44)\end{array}$ & $\begin{array}{c}\text { Deaths after } \\
\text { discharge } \\
(\mathrm{n}=30)\end{array}$ \\
\hline $\begin{array}{l}\text { Hard tissues, } \mathrm{n}(\%) \\
209(83.27)\end{array}$ & $135(86.54)$ & $44(78.57)$ & $30(76.92)$ \\
Le Fort & $28(13.39)$ & $18(13.33)$ & $5(11.36)$ & $4(13.33)$ \\
$\begin{array}{l}\text { Nasoorbitoethmoid } \\
\text { complex }\end{array}$ & $141(67.46)$ & $93(68.89)$ & $27(61.36)$ & $21(70.0)$ \\
$\begin{array}{l}\text { Zygomatic complex } \\
\text { Mandible }\end{array}$ & $136(65.07)$ & $107(79.26)$ & $19(43.18)$ & $20(66.67)$ \\
Maxilla & $71(33.97)$ & $54(40.0)$ & $9(20.45)$ & $8(26.67)$ \\
\hline
\end{tabular}

Table 3. Distribution of patients according to wards, maxillofacial surgery, hospital mortality and death after discharge.

\begin{tabular}{lc}
\hline Category & $\begin{array}{c}\text { Total } \\
(\mathrm{n}=209)\end{array}$ \\
\hline Ward, $\mathrm{n}(\%)$ & $136(65.07)$ \\
Neurosurgery & $58(27.75)$ \\
Maxillofacial surgery/Stomatology & $57(27.27)$ \\
Ophthalmology & $15(7,18)$ \\
Otorhinolaryngology & $6(2.87)$ \\
Maxillofacial surgery, $\mathrm{n}(\%)$ & $49(23.44)$ \\
1 Surgery & $38(18.18)$ \\
2 Surgeries & $6(2.87)$ \\
3 Surgeries & $3(1.44)$ \\
$>3$ Surgeries & $2(0.96)$ \\
Hospital mortality, $\mathrm{n}(\%)$ & $44(21.05)$ \\
$<2$ days & $7(3.35)$ \\
2 days & $6(2.35)$ \\
$>2$ days & $31(14.83)$ \\
Death after discharge, $\mathrm{n}(\%)$ & $30(14.35)$ \\
$<6$ months & $11(5.26)$ \\
\hline
\end{tabular}

Zygomatic complex fractures occurred in $65.07 \%$ of patients; Le Fort and mandible fractures accounted for 13.39\% and 33.97\% respectively (Table 2 ).

Among the survivor population, 136 patients (65.07\%) were followed in different wards with 58 (27.75\%) being treated in neurosurgery and $57(27.27 \%)$ in maxillofacial surgery and stomatology (Table 3 ).

A total of 49 (23.44\%) patients underwent maxillofacial surgery. Of these, $38(18.18 \%)$ had one surgery only, $6(2.87 \%)$ had two surgeries, $3(1.44 \%)$ had three surgeries, and $2(0.96 \%)$ had more than three surgeries (Table 3 ).

Concerning hospital mortality, 7 (3.35\%) individuals died within less than two days after admission, 6 (2.35\%) within two days after admission and 31 (14.83\%) later than 2 days after admission into the ER. As for mortality after discharge, 11 $(5.26 \%)$ patients died within less than six months, 5 (2.39\%) between six and twelve months, and $14(6.7 \%)$ died more than twelve months after discharge (Table 3).

\section{Discussion}

Epidemiologically, the proportions of patients with facial trauma are similar to those of other serious polytrauma. This study found $86.6 \%$ patients with head injuries and diagnosed with traumatic brain injury and a total of $53(25.36 \%)$ individuals did not survive. In another study, in $89.24 \%$ of cases, traumatic brain injury (17) was also present, which is itself a determinant of the outcome, and it is impossible to dissociate the mortality and morbidity of maxillofacial trauma associated with it. The majority of published studies in literature indicate a prevalence of this type of injury in males (18). Results agree with most published literature about this subject, as 181 of the $209(84.86 \%)$ individuals were male, while only 28 were female. In this sample, 131 males and 25 females survived.

In the present study, the 30-39 year age group was the most affected by maxillofacial trauma, with 34 patients. Of these, $16.3 \%$ survived, $22.73 \%$ died in hospital and $6.67 \%$ died after discharge. In a similar study, the authors reported similar values, with the most frequently affected age group being 21-30 years (19).

Studies about the etiology of maxillofacial fractures found road traffic accidents, assault, occupational accidents and domestic accidents to be the main causes (20). Road traffic accidents were responsible for $69.38 \%$ of injuries observed in this study, indicating that these results are consistent with existing literature regarding the most common etiology of maxillofacial fractures (21).

The number of maxillofacial surgeries is an indirect way to evaluate the global incidence of maxillofacial fractures in polytrauma patients. The data show that 49 
(23.44\%) patients underwent maxillofacial surgery, with $38(18.18 \%)$ patients having one surgical intervention only. Other authors demonstrated that $44 \%$ of patients with maxillofacial trauma were admitted to maxillofacial surgery, a higher value than the one found in this study (22). This study found that the most common location for fractures was the nasoorbitoethmoid complex with 141 $(67.46 \%)$ cases, while other authors recorded 87 (66\%) cases of mandible fractures (23). Another study recorded the zygomatic complex as the most affected structure (64\%), followed by the nasoorbitoethmoid region (24), but none severely injured patients.

This study presents an analysis based on a prospective database, although retrospectively analyzed, and is one the first to analyze maxillofacial fractures in the severely injured patients (mostly adults). The maxillofacial fractures patients may experience a variety of injuries in other regions of the body and these associated injuries worsen the maxillofacial trauma prognostic as some of them may result in functional disabilities or even death.

In conclusion, this study provides relevant data on patterns of maxillofacial and dental trauma in a specific population (severely injured patients) and plays a role in multiple mortality and morbidity cases. The society should have a key role in awareness of individuals and in prevention of road traffic accidents.

\section{Resumo}

É alta a incidência de traumas na face. Este estudo teve por objetivo documentar e catalogar as fraturas maxilofaciais em pacientes com politraumatismos. De um total de 1229 casos de politraumatizados tratados na Sala de Emergência do Hospital de Santo António - Centro Hospitalar do Porto, Portugal, entre Agosto de 2001 e Dezembro de 2007, 251 pacientes tiveram ferimentos na face e 209 apresentaram fraturas maxilofaciais. As idades variaram de 13 a 86 anos. 0 método de seleção baseou-se na presença de ferimentos na face com Abreviated Injury Scale $\geq 1$. Os homens apresentaram maior incidência de fraturas maxilofaciais $(86,6 \%)$ entre os pacientes com múltiplos traumatismos na face e os acidentes de trânsito foram a causa principal dos traumatismos $(69,38 \%)$. A região mais afetada foi o complexo naso-órbito-etmoidal $(67,46 \%)$, seguido pela maxila $(57,42 \%)$. 0 padrão e a apresentação das fraturas maxilofaciais tem sido estudado em muitas regiões do mundo com resultados variados. Pacientes com politraumatizados graves apresentaram padrões diferentes de traumatismos maxilofaciais. 0 número de traumatismos maxilofaciais tem aumentado à escala mundial, assim como a incidência das sequelas associadas. Entre os pacientes com traumatismos múltiplos, a maioria pertencia ao sexo masculino, assim como a causa mais frequente foram os acidentes automobilísticos. É elementar o conhecimento destes dados. A sociedade tem um papel primordial nos cuidados individuais e na prevenção dos acidentes de trânsito.

\section{References}

1 Peden M, Scurfield R, Sleet D, Mohan D, Hyden AA, Jarawan E, et al., editors. World Report on Road Traffic Injury Prevention. Geneva: WHO, 2004.

2 Momeni $H$, Shahnaseri $S$, Hamzeheil Z. Distribution assessment of maxillofacial fractures in trauma admitted patients in Yazd hospitals: An epidemiologic study. Dental Research Journal 2011;8:80-83.
3. Roccia F, Boffano P, Bianchi FA, Gerbino G. Maxillofacial injuries due to work-related accidents in the North West of Italy. Oral Maxillo Surg 2012;7:181-186.

4. Elhammali N, Bremerich A, Rustemeyer J. Demographical and clinical aspects of sports-related maxillofacial and skull base fractures in hospitalized patients. Int J Oral Maxillofac Surg 2010;39:857-862.

5. Shahim FN, Cameron $P$, McNeil JJ. Maxillofacial trauma in major trauma patients. Australian Dental Journal 2006;51:225-230.

6. Businger AP, Krebs J, Schaller B, Zimmermann H, Exadaktylos AK. Cranio-maxillofacial injuries in victims of interpersonal violence. Swiss Med Wkly 2012;142.

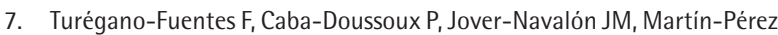
$E$, Fernández-Luengas $D$, Diez-Valladares $L$, et al.. Injury patterns from major urban terrorist bombings in trains: the Madrid experience. World J Surg 2008;32:1168-1175.

8. Levin L, Zadik Y, Peleg K, Bigman G, Givon A, Lin S. Incidence and severity of maxillofacial injuries during the Second Lebanon War among Israeli soldiers and civilians. J Oral Maxillofac Surg 2008;66:1630-1633.

9. Mock C, Quansah R, Krishnan R, Arreola-Risa C, Rivara F. Strengthening the prevention and care of injuries worldwide. Lancet. 2004;363:21722179.

10. Gassner R, Tuli T, Hächl O, Rudisch A, Ulmer H. Cranio-maxillofacial trauma: a 10 year review of 9,543 cases with 21,067 injuries. J Craniomaxillofac Surg 2003;31:51-61.

11. Statistical Portugal. Statistical Yearbook of Portugal. 2010-2011:11.

12. Thorén H, Snäll J, Salo J, Suominen-Taipale L, Kormi E, Lindqvist C, et al.. Occurrence and types of associated injuries in patients with fractures of the facial bones. American Association of Oral and Maxillofacial Surgeons 2012;68:805-810.

13. Rhodes G. The evolutionary psychology of facial beauty. Annual Review Psychology 2006;57:199-226.

14. Alves LS, Gomes E, Dias C, Sousa MJC. Characterization of dental and maxillofacial trauma by traffic or work-related accidents - from the epidemiology to the results. Rev Port Estomatol Med Dent Cir Maxilofac 2008:49:197-204.

15. Alves LS, Sousa MJ, Gomes E. Retrospective analysis of 186 cases of maxillofacial trauma from road traffic accidents. Rev Port Estomatol Med Dent Cir Maxilofac 2013;54:179-184.

16. Greenspan L, McLellan BA, Greig H. Abbreviated injury scale and injury severity score: a scoring chart. J Trauma 1985;25:60-64.

17. Ozkaya O, Turgut G, Kayali MU, Ugurlu K, Kuran I, Bas L. A retrospective study on the epidemiology and treatment of maxillofacial fractures. Ulus Travma Acil Cerrahi Derg 2009;15:262-266.

18. Santos AAR, Moura MEB, Nunes BMVT, Leal CFS, Teles JBM. Profile of motorcycle accident victims treated at a public hospital emergency department. Cad Saúde Publica 2008;24:1927-1938.

19. Chrcanovic BR, Freire-Maia B, Souza LN, Vasco de Oliveira Araújo VO, Abreu MHNG. Facial fractures: a 1-year retrospective study in a hospital in Belo Horizonte. Braz Oral Res 2004;18:322-328.

20. Lin S, Levin L, Goldman S, Peled M. Dentoalveolar and maxillofacial injuries: Retrospective study from a Level I trauma Center in Israel. Dent Traumatolog 2007;23:155-157.

21. Venugopal MG, Sinha R, Menon PS, Chattopadhyay PK, Roy Chowdhury SK. Fractures in the maxillofacial region: A four-year retrospective study. MJFAI 2010;66:14-17.

22. Martini MZ, Takahashi A, Oliveira Neto HG, Carvalho Júnior JP, Curcio R, Shinahara EH. Epidemiology of mandibular fractures treated in a Brazil Level I Trauma Public Hospital in the city of São Paulo, Brazil. Braz Dent J 2006;17:243-248.

23. Valente RO, Souza LC, Antonini SV, Glock L, Castro Neto WN. Epidemiologia das fraturas mandibulares atendidas no Hospital da Santa Casa de Misericórdia de São Paulo (HSCSP) entre 1996 e 1998. Rev Brás Cir Period 2003;2:141.

24. Chalya $\mathrm{PL}$, Mchembe M, Mabula JB, Kanumba ES, Gilyoma MJ. Etiological spectrum, injury characteristics and treatment outcome of maxillofacial injuries in a Tanzanian teaching hospital. J Trauma Manag Outcomes 2011;5:7. 